\title{
Penal reform in Africa: The case of prison chaplaincy
}

\begin{tabular}{|c|c|}
\hline $\begin{array}{l}\text { Authors: } \\
\text { Abraham K. A } \\
\text { Yolanda Dreye }\end{array}$ & \\
\hline $\begin{array}{l}\text { Affiliations: } \\
{ }^{1} \text { Department } \\
\text { Theology, Fac } \\
\text { Theology, Uni } \\
\text { Pretoria, Sout }\end{array}$ & $\begin{array}{l}\text { Practical } \\
\text { ulty of } \\
\text { eersity of } \\
\text { Africa }\end{array}$ \\
\hline $\begin{array}{l}\text { Research Proj } \\
\text { Project Leade } \\
\text { Project Numb }\end{array}$ & $\begin{array}{l}\text { ect Registration: } \\
\text { r: Y. Dreyer } \\
\text { er: } 2546930\end{array}$ \\
\hline $\begin{array}{l}\text { Description: } \\
\text { Dr Akih is part } \\
\text { research proje } \\
\text { Studies and P } \\
\text { Theology The } \\
\text { directed by Pr } \\
\text { Dreyer, Depar } \\
\text { Theology, Fac } \\
\text { Theology, Uni } \\
\text { Pretoria. }\end{array}$ & $\begin{array}{l}\text { icipating in the } \\
\text { ct, 'Gender } \\
\text { actical } \\
\text { ory Formation', } \\
\text { of. Dr Yolanda } \\
\text { tment Practical } \\
\text { lty of } \\
\text { rersity of }\end{array}$ \\
\hline $\begin{array}{l}\text { Correspondin } \\
\text { Yolanda Dreye } \\
\text { yolanda.dreye }\end{array}$ & $\begin{array}{l}\text { g author: } \\
\text { r, } \\
\text { r@up.ac.za }\end{array}$ \\
\hline $\begin{array}{l}\text { Dates: } \\
\text { Received: } 13 \\
\text { Accepted: } 13 \\
\text { Published: } 31\end{array}$ & $\begin{array}{l}\text { eb. } 2017 \\
\text { May } 2017 \\
\text { Aug. } 2017\end{array}$ \\
\hline $\begin{array}{l}\text { How to cite th } \\
\text { Akih, A.K. \& D } \\
\text { 'Penal reform } \\
\text { case of prison } \\
\text { HTS Teologies } \\
\text { Theological St } \\
\text { a4525. https:/ } \\
10.4102 / \text { hts.V }\end{array}$ & $\begin{array}{l}\text { is article: } \\
\text { reyer, Y., 2017, } \\
\text { in Africa: The } \\
\text { chaplaincy', } \\
\text { e Studies/ } \\
\text { udies } 73(3) \text {, } \\
\text { /doi.org/ } \\
73 i 3.4525\end{array}$ \\
\hline $\begin{array}{l}\text { Copyright: } \\
\text { (c) 2017. The } \\
\text { Licensee: AOS } \\
\text { is licensed un } \\
\text { Creative Comr } \\
\text { Attribution Lio }\end{array}$ & $\begin{array}{l}\text { Iuthors. } \\
\text { IS. This work } \\
\text { ler the } \\
\text { nons } \\
\text { ense. }\end{array}$ \\
\hline Read online: & \\
\hline 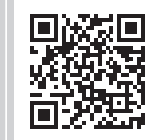 & $\begin{array}{l}\text { Scan this QR } \\
\text { code with your } \\
\text { smart phone or } \\
\text { mobile device } \\
\text { to read online. }\end{array}$ \\
\hline
\end{tabular}

Penal reform is a challenge across the world. In Africa, those who are incarcerated are especially vulnerable and often deprived of basic human rights. Prison conditions are generally dire, resources are limited, and at times undue force is used to control inmates. The public attitude towards offenders is also not encouraging. Reform efforts include finding alternative ways of sentencing such as community service, making use of halfway houses and reducing sentences. These efforts have not yet yielded the desired results. The four principles of retribution, deterrence, incapacitation and rehabilitation guide penal practice in Africa. Retribution and rehabilitation stand in tension. Deterrence and incapacitation aim at forcing inmates to conform to the social order. The article argues that prison chaplaincy can make a valuable contribution to restoring the dignity and humanity of those who are incarcerated. Chaplaincy can contribute to improving attitudes and practices in the penal system and society. In addition to the social objective of rehabilitation, prison ministry can, on a spiritual level, also facilitate repentance, forgiveness and reconciliation. The aim is the holistic restoration of human beings.

\section{Prisons in Africa: A challenge}

Crime is a social construct created by those in power who determine what is criminal and what deserves severe punishment because it poses a threat to the security and order of society. People who are detained in African prisons are not only deprived of their freedom as punishment for their crimes, but are often also deprived of the basic necessities of life. Imprisonment in Africa brings with it untold hardship and suffering, especially where power is abused and force is used to control prison inmates. Prisons can be oppressive structures that do not contribute to 'correction', as the name 'Correctional Services' would suggest, but rather to creating delinquents, categorising and isolating 'criminal types' and constructing a new category of 'social objects' (see Atabong 2007:1; Dissel 2007:155). Penal systems on the continent of Africa face many challenges. Public ignorance and disinterest allow the negligence and abuse in prisons in Africa to go largely unchecked.

Prisons in general have an unhappy and violent history, the consequences of which are described by Michel Foucault (1979:9) as follows: 'Punishment is the most hidden part of the penal process and inmates have been the most invisible of the poor'. According to Skotnicki (2008:27), this calls for a more humane vision and model for punishment in the global world. The generally accepted approach that incarceration is the appropriate punishment for the perpetrators of crime has also been adopted in Africa. The old colonial prison structures that are still used are an affront to the dignity of human life. Resources for penal reform are scarce, healthcare facilities are inadequate and the spread of communicable diseases among inmates is not curbed effectively (see Dissel 2007:156). This is also because of the overcrowding of prisons on the continent.

South Africa, followed by Botswana, Swaziland and Lesotho, has the highest rate of incarceration (Sekhonyane 2005:1). South Africa's minimum sentencing legislation contributes to an increase in the number of inmates who are sentenced to serve long prison terms. In Zambia and Cameroon no new prisons have been constructed since independence. Dilapidated walls and broken fences are characteristic of most penal systems on the continent. In June 2001, the United Nations' Special Rapporteur visited Malawi and noted that medical personnel were only employed part-time, while the spread of communicable diseases and declining health conditions were escalating. The judicial system is often extremely slow, which means that people spend a long time awaiting trial.

The legal framework and colonial laws still prevail in most African countries. The United Nations' Special Rapporteur for prisons and conditions of detention in Africa expresses dismay at the state of penal systems on the continent. Reports to the United Nations and the African Union indicate

Note: This article is a reworked version of aspects from the PhD thesis of Abraham. K. Akih, titled 'An African pastoral perspective on prison chaplaincy', in the Department of Practical Theology, University of Pretoria with Prof Yolanda Dreyer as supervisor. 
that poor nutrition and hygiene, escalating deaths in congested cells, human rights abuses and a scarcity of recreational and rehabilitative facilities are the order of the day (African Charter on Human and Peoples' Rights [ACHPR] 2010:1).

Retribution, deterrence, incapacitation and rehabilitation are the stated aims of penal practice in Africa. It has become necessary to assess which of these have a constructive effect and should be upheld and which rather lead to punitive and socially repressive practices. In effect, retribution, deterrence and incapacitation stand in tension with rehabilitation. Some penal documents express the aim that all four of these should be held 'in balance' (see Compendium 2006:27). However, the main focus is mostly on retribution and rehabilitation, which are central to both existing penal practices and revolutionary reform experiments in the global world. Skotnicki (2008:61) points out that prison officials have but limited possibilities to infuse meaning and humanity into the punishment and rehabilitation process. According to Skotnicki (2008:141), penal reform is not committed to coherent human symbols and practices because the protection of society remains the primary goal. Even penal reform is directed more at effective social control which is less expensive than at improving the lives of the people in the system (Skotnicki 2008:139). Skotnicki (2008:141) points out that 'alternatives to imprisonment need far more nuance than is currently being provided'.

A vision of prison reform in Africa has been born and is to be executed by the 'Prisoners' Rehabilitation and Welfare Action' (PRAWA). However, this body has not yet succeeded in showing the way towards the tangible improvement of the lives of inmates and penal systems in Africa (ACHPR 2010:1). The vision of PRAWA is not sufficiently put into practice in most countries.

PRAWA is supported by the Netherlands Agency of Correctional Institutions. The first part of the project involves the baseline assessment of practices and situations in six selected countries: Nigeria, Kenya, Rwanda, Democratic Republic of Congo, Burundi and Zambia. However, a uniform data collection exercise in Africa, which could make a comparative analysis, effective intervention and an evaluation of best practices possible, has proven difficult. To carry out relevant, effective and sustainable interventions in the area of penal reform, a baseline assessment of the current situation of prisons in Africa has to be done. It is the task of PRAWA to do the necessary research that can identify the problems, assess their impact and develop effective intervention strategies. PRAWA does conduct and promote regular data collection exercises with the aim to provide accurate information for further research and the development of penal reform. In 2010, studies were conducted by PRAWA in Nigeria, Kenya, Rwanda, the Democratic Republic of Congo, Burundi and Zambia. However, the data that were collected are still being analysed and interpreted. This means that the process is rather lengthy because of limited human and financial resources. Therefore, solutions are not forthcoming.
Africa as a whole is in need of a re-evaluation of its criminal justice systems and should explore new ways of fighting crime. The development of strategies for crime prevention and reduction should be ongoing. New ways to make prisons self-reliant and self-sufficient should be investigated. The potential of inmates should be developed and they should be empowered to live a crime-free life once they have been released from prison. Rehabilitation programmes should focus on the reintegration of people who were in prison back into society. Such programmes should also contribute to the personal and social development of the inmates themselves.

Penal reform in Africa gained momentum round about the mid-1990s. In 1996 the first Pan-African Seminar on the Conditions of Detention took place in Kampala, Uganda. More than 130 delegates from various African countries participated. The Kampala Declaration on Prison Conditions in Africa was adopted. The declaration compelled the ACHPR to work towards improving prison conditions, nominate a special rapporteur to sensitise the African Union and its members to respect international standards, set up a legal framework of cooperation with non-governmental organisations (NGOs) and relevant stakeholders that would ensure follow-up.

The United Nations Special Rapporteur was established in terms of Article 45 of the ACHPR and has the mandate to monitor the living conditions of inmates, identify institutional problems and make recommendations for improvement. The Ouagadougou Declaration of 2000 and the resultant plan of action focus on the Kampala Declaration (1996), the Kadoma Declaration on Community Service in Africa (1997) and the reports of the special rapporteur. Since then, some mechanisms were put in place to improve prison conditions in Africa. Prison Reform International collaborates with some African nations to design projects for the implementation of community service as an alternative to incarceration. Community service was started in Zimbabwe in 1994.

In 1997, an international conference on community service as an alternative to incarceration in Africa was held in Kadoma (Zimbabwe). The Kadoma Declaration was accepted and a plan of action proposed. This led to the implementation of community service in Kenya, Malawi, Burkina Faso, Congo Brazzaville, Central African Republic and Mozambique in 1999. Uganda adopted legislation for alternative sentencing in 2000. Senegal, Tanzania and Namibia followed and adopted community service legislation in 2002.

In 2002, in Ouagadougou (Burkina Faso), 123 delegates from 34 African countries gathered to follow-up on the Kampala Declaration. The goal was to assess the progress made since 1996 and identify new models for dealing with crime on the continent. In November 2003, the 34th session of the ACHPR took place in Banjul (Gambia). The Ouagadougou Declaration on accelerated penal reform in Africa was adopted. A plan of action was put in place for relieving overcrowding in prisons, making prisons more self-reliant, promoting the reintegration 
of ex-inmates into society and encouraging best practice among penal staff. The plan was enhanced by incorporating restorative and traditional justice programmes, providing referral mechanisms and decriminalising certain offenses.

Most African countries ratified the body of international laws relating to penal reform. These governments are required to enforce international stipulations and report regularly on progress made in their respective countries, especially with regard to human rights issues. Ghana has, for instance, opened their prisons to be visited by members of the public once a year so that the public can see what the conditions in the prisons are like. Through such visits, communities come to realise that prisons do not solve the problem of crime. The visits also generate public discussions on penal reform and good prison management. Judicial inspection of prison living conditions takes place regularly in South Africa and Malawi. Other nations, such as Cameroon, have established a human rights commission which checks for abuse or violations relating to human dignity and worth. They also see to it that perpetrators are brought to justice. Complaints are heard by these commissions and remedial action is taken.

However, most African governments have not fully complied with international standards mostly because of a lack of adequate legislation, resources, training and personnel and the drawback of a very limited budget. Legislation in many African countries does not yet align with international standards. Some outdated laws such as, for example, rogue and vagabond laws have not yet been abolished. Where prisons are in a state of disrepair, they will have to be renovated or rebuilt. In order to address this challenge, resources will have to be found.

Prison systems in Africa are caught between a colonial heritage of inappropriate and anachronistic legislation and a turbulent transition to independence. Institutions that undergird a strong and vibrant democracy are still in the process of being developed. Given the problem of limited resources, penal reform in Africa should focus on a limited number of key objectives. Governments should be transparent and generate constructive ideas for building capacity and developing potential. The prison population can be reduced if effective local solutions can be found. Much can be achieved if there is political will. Africa requires criminal justice solutions that reflect the realities of the continent. Sustainable solutions take time to develop. This is the nature of true transformation.

Penal systems should develop strategies for rebuilding trust in those citizens who have committed a crime rather than revert to forceful interventions and social control methods. These have not proven to be effective in the fight against crime (see Skotnicki 2008:2). Prisons in most countries mirror the weakening moral, economic, social and political life of the nation. Imprisonment entails the separation from family, friends, loved ones and a familiar environment. People are removed from their lives and thrown into a cold and unfamiliar environment to face prison routine with its arbitrary and callous nature. The character, life and history of the people who have been incarcerated are not taken into account and neither are the circumstances that led to crime taken into account during sentencing. Worldwide there has been an effort towards the rehabilitation and reintegration into society of people who have spent time in prison. This article argues that humanist, spiritual and religious practices can contribute to more meaningful identities for inmates and people who are released from prison.

\section{The role of religion, spirituality and pastoral care}

In the history of prison systems, religious personnel were often at the forefront of treatment programmes and provided solace and asylum to inmates. The punitive character of prisons and the challenges that inmates face on a day-to-day basis call for spiritual, intellectual and religious care. Not only individual care is needed but also the contribution of religious personnel to forging the policies of the prison. In developed nations, there is more opportunity for input from their side than is currently the case in developing countries (see Skotnicki 2008:2). Punishment does not accomplish its objective until it is focused on healing and reform.

Penal reform should aim at intervention, treatment and rehabilitation. According to Griffith (1995:40, 41), it should promote the notion of inmates as residents, prison staff as correctional officers and cells as adjustment units. It is important that the training of penal officials include knowledge on basic human rights and the international norms and standards on the treatment of inmates. NGOs and civil society should regularly monitor prisons to ensure that governments meet domestic and international human rights obligations towards inmates. NGOs and civil society should encourage and organise retreats and workshops for penal officials to inform them of best practices in other prisons in Africa and the world. They should support governments by assisting in promoting the welfare of inmates. Prison culture can be a stumbling block for rehabilitation efforts. Creative ways to support healthy growth and change negative habits that promote crime should be found. In this regard, chaplaincy can play an significant role. A theology of pastoral care in prisons will focus on honesty, integrity and consistency (Roberts 2012:17).

Chaplaincy came into being in situations where pastoral and spiritual care were deemed valuable to help people to cope in crisis situations. One such environment is the military and another is hospitals. Military and healthcare chaplaincies are well documented (Paget \& McCormick 2006:3), prison chaplaincy not to the same extent. Prison chaplaincy requires a specific set of skills and an understanding of the prison environment and system as well as of the people who are incarcerated and those who work there (see Roberts 2012:22).

It is a challenge for chaplains in Africa to visualise what it means to do pastoral care in prisons on the continent. Social constructionist theories assume the existence of multiple 
realities with meanings that emerge from shared interactions of individuals in community (Swinton \& Mowat 2006:35). Constructive meaningful learning takes place when individuals engage in social activities which provide a glimpse of reality and its challenges (Kim 2001:3). Living human documents are dialogical in their encounters with other worldviews. The chaplain's self is formed through intimate relations with God and the community. The self and interior life of chaplains are the primary space where pastoral and theological awareness is generated and nurtured (see Graham, Walton \& Ward 2005:6). Chaplains and chaplaincy in an African context will have to be flexible and adapt to circumstances. A chaplaincy model from elsewhere cannot simply be imported and applied.

The work environment of chaplains in prisons all over the world consists of a variety of religious traditions, cultural backgrounds and understandings of God. In this context, it is a challenge for chaplains to preserve both their pastoral integrity in the interaction with people and their prophetic voice as bearers of the gospel message of justice and grace. Professional chaplaincy in UK, US and Canada has had to evolve from a mainline church-oriented service to what it is today (Roberts 2012:xi). Major chaplaincy boards and organisations in Canada and the US host conferences and workshops with leaders and work together to develop the field of prison chaplaincy. This is not the case in Africa where, without much preparation or much of a welcome from the side of the penal institutions, chaplains attempt to gain access to prisons in order to help facilitate healing and transformation. For chaplains in Africa, there are not many possibilities for training where they can learn the basic skills necessary for effective and professional chaplaincy and spiritual and pastoral care. Strategies for improvement, planning, research and the ability to develop and implement tactical plans are needed in this highly challenging environment (see Roberts 2012:xi-xii).

Punishment strategies should be geared towards social reintegration and spiritual and relational healing of both inmates and those who serve the penal institution. Penal reform should be seen as a harmonious and equitable social project. It should be approached in terms of liberation from oppression, marginalisation and social stigma. The prophetic vision of justice is the liberation of the oppressed from captivity (see Skotnicki 2008:132).

Religion can be described as 'the practice of a particular system of faith and beliefs in a cultural setting' (Paget \& McCormick 2006:17). Spirituality is the search for understanding that connects beliefs and values to give meaning to life. There are many ways in which religion functions in prison: it can serve as an escape route for the loneliness and boredom inherent to prison life and culture. It can be a means to forget or atone for the past. Religion can facilitate a conversion experience and the formation of a new identity. It can be a way to find a sense of belonging or do something useful with the time in prison. Religion also provides more than an identity, a coping mechanism or an occupation. It is a way of life that enables people to connect with and make their peace with the 'self' (Denend 2007:397). The essence of religion includes the willingness to change and grow, also while incarcerated.

\section{Prison chaplaincy}

In the context of Africa, there are but few avenues for chaplains to collaborate, learn from one another and find solutions to the great variety of problems and issues related to their work environment. The field of prison chaplaincy in Africa is still undergoing professional development. There is a need for chaplains in Africa to engage with one another and develop a theology of spiritual and pastoral care for their particular context, both that of Africa and that of the penal environment. This would focus on advocacy, relevancy and understanding and would emphasise the humanity of the inmates and the grace of God who offers redemption to all of fallen creation (see Roberts 2012:13). Chaplains face the challenge of remaining true to their beliefs while simultaneously being open to and accommodating others' views and respecting their experiences, loving people as they are. Chaplaincy services could provide an opportunity for marginalised groups to speak and make their voices heard on penal issues. The quest of prison chaplaincy in Africa is to gain clarity with regard to its role, value, contribution and possibilities.

Not only in Africa but also elsewhere in the world, including in the US (see Denend 2007:395), there is a scarcity of prison chaplains. Chaplains who work in African prisons often do not have an office and often there is no space or area where they can meet with inmates and do counselling with them. They usually meet informally with inmates during 'down time' and during the periods reserved for religious services. These settings are in to some extent 'outside' of daily life in prison. Every ministry is at heart informal as it occurs simply and without notice through talks or conversations on individual, family and community issues (Denend 2007:396). Interaction with the chaplain can have a significant impact on the lives of inmates. Chaplains become part of a community with its own history, stories and but a slim chance of joy and laughter. In such spaces, chaplains discover the benefits and tensions of being both insiders and outsiders in the penal institution. With both these perspectives, chaplains seek to find a balance between being open and honest as well as wise and wary. The inmates' perception of the chaplains can present difficulties. There can be differences in their faith traditions; there mostly is a vast difference in their educational status, as well as their values and understanding of life and the world. It is the task of the chaplain to try and bridge this divide and transcend the differences for the good of all.

The atmosphere community chaplains aim to create among inmates counteracts the divisive nature of penal institutions. Prison chaplaincy provides a space where differences are acknowledged, understood and used creatively to knit a common story. It is often a difficult task with many setbacks. Chaplains have to tread cautiously, honestly and passionately 
to overcome the barriers inherent to the context of prison ministry. With regard to the level of intimacy, providing comfort and acceptance to people who are incarcerated, chaplains can do more than penal officials. The presence and work of the chaplain can facilitate breaking down barriers, binding people together, healing wounds and restoring relationships with families and with the victims of crime. Chaplains strive to provide solutions with regard to spiritual issues and to promote good, constructive values, a better understanding of the self and the world and inner peace among the people they work with.

Chaplains cannot force their values onto others, but in being together with the inmates, chaplains can help them find a meaningful way out of their every crisis. There is power in negotiating boundaries through being still together, listening attentively and loving the other. In solidarity with inmates, chaplains can experience their life stories and try to understand not only the pain inherent to being human but also the specific pain of that particular life. Chaplains seek to connect and relate to the stories of inmates even though their own life experiences are so very different. The emotions and sentiments in every story are human and real. Chaplains create and share a sacred space with inmates. They experience a 'togetherness' that is an act of resistance to a system intended to divide and break relationships. In the shared sacred space, chaplains and inmates discover a spiritual place where they can come closer to healing and restoration. Silence, solitude, prayer, fasting and work are spiritual and human resources for promoting integrity and psychological and spiritual well-being (see Skotnicki 2008:135). The aim is for the prison cell to become a place for people to find their true identity and root out the impulses and influences that have alienated them from others, nature and God. While in custody, inmates should be given the best opportunity to receive encouragement and counselling from wise and caring people who know and visit them regularly.

\section{A holistic approach to prison pastoral care}

A holistic model of pastoral care involves the whole person on all levels of human existence. Chaplains are the only service providers in prisons who also address the religious and spiritual needs of people. They attend to people of various faith traditions and also to those who profess no religion. Chaplains can contribute to building up the coping skills of all concerned: the inmates themselves, the victims of the crime and the families and communities of the various parties. Chaplains facilitate people to discover meaning and purpose for their existence. Through spiritual connection and religious practices, they aim to bring people in touch with what they held (and maybe deep down still hold) sacred. Religious and spiritual beliefs and practices can be or become a major part of how inmates cope with prison life and culture.

A lack of clarity on the role of chaplains and pastoral caregivers can get in the way of the success of this work (see Roberts 2012:24). Chaplaincy will have to make a clear contribution operating by consensus rather than consisting of isolated activities in a silo (Roberts 2012:29). If pastoral and spiritual care remains the sole prerogative of chaplains, it will continue to be marginalised. The collaboration of chaplains and volunteers from different walks of life can provide a much broader scope of care in order to bridge the gap between the institution and society. Chaplains then become the facilitator of a team of volunteers. The chaplain has a special knowledge of the institution and of the holistic care process and can equip the volunteers for their collaborative work.

Chaplaincy in many instances remains a peripheral service with its practitioners serving at the edge and margins of society. A non-directive approach to pastoral care is geared towards the development of coping skills. Through a ministry of presence and active listening, the focus is on the inner life of inmates in order to facilitate a better understanding and a more effective functioning in their environment. The opportunity for such an inward-focused pastoral care presents itself especially during moments of crisis and grief. There is a need for pastoral care that helps inmates to develop a worldview that differs from that which caused them to end up in prison in the first place. It is essential to engage the thinking patterns of inmates in ways that support healthy growth and the transformation of their lifestyle.

Existing literature on pastoral care and prison chaplaincy in Africa indicates that chaplains consider pastoral counselling to be their primary task in the penitentiary system (see Pew Forum on Religion and Public Life 2012:12; Romeril \& Tribe 1995:383). Chaplains provide religious and spiritual care in various ways, such as, providing access to volunteer workers of faiths other than those represented by the permanent personnel. They also lead services, officiate in ceremonies and facilitate rituals. Studies that focus specifically on how to improve pastoral care and chaplaincy in the penal systems of Africa are scarce (see Brault 2014; Hausmann \& Spooner 2009:215; Kusada 2014:iv). It is therefore necessary to explore the context of chaplaincy in African prisons and investigate the work chaplains do in practice. Insights gained from such an investigation will help to identify the needs of and best practices in penal institutions. It will show how, in practice, chaplains integrate spirituality with the treatment efforts of the institution in order to achieve a stronger positive result. Chaplaincy has the potential to foster religious engagement and practices that can contribute to the rehabilitation of inmates and even to the transformation of prisons.

It is possible through chaplaincy to develop and nurture practices of pastoral care and counselling that can make a difference in the lives of inmates. Studies by Hausmann (2004:215) show a positive correlation between time spent with chaplains and transformed lifestyle and behaviour by inmates after release from prison. Youths who receive supportive pastoral counselling during custody are less likely to reoffend when released and returned to the social community (see Hausmann \& Spooner 2009:216). In the Western world, successful rehabilitation revolves around the 
principles of risk, needs and responsivity (see Scott 2008; Warren 2007). The chaplains' role is not 'treatment' but, with their specialist knowledge, to assess the qualities and characteristics of people and programmes that could make a difference (Brault 2014:2). They can then facilitate religious engagement that will be effective in the prison environment.

Effective practices target particular needs and characteristics of inmates that could deter them from future criminal activities. Effective interventions can contribute to the reduction of reoffending behaviour and can help inmates to go out and live a prosocial and crime-free life. According to Thomas and Zaitzow (2006:255), religious conviction can serve as a 'correction' with regard to the attitudes and behaviour of those in custody. Religious convictions go hand in hand with a specific attitude, specific behaviour and an expectation as to how others are to be treated and how one is to respond in difficult circumstances. Pastoral care can help inmates to understand and respond to the challenges of life and how to transform a bad attitude and transform destructive behaviour. Religion can give meaning and purpose to life through providing moral and ethical guidelines.

In the context of Africa, pastoral care, counselling and chaplaincy could help inmates to transcend the immediate reality, connect to that which is beyond them and help them adapt to challenges and circumstances of prison life and culture (see Brault 2014:2). A healthy religious orientation can serve to support an optimistic worldview and provide spiritual resources for inmates and community (Koenig 1995). Chaplains and religious personnel who are an extension of and representative of the community outside prison can provide a substitute for social support (Romeril \& Tribe 1995:384). They can also facilitate the reconnection of people who have been released from prison with their communities. The social and communal bonds forged by religious personnel can serve as a frame of reference for inmates with regard to community, identity, a sense of belonging and tradition. Such social bonds can foster subcultures, 'niches, and sanctuaries' that can help inmates avoid insulating themselves from the challenges of prison life and culture (Johnson 1996:98). Niches are rehabilitative to the degree that they facilitate self-improvement, emotional support, community involvement, meaningful activity and the development of mature coping skills. Social bonds not only affect the choices inmates make but are instrumental in integrating beliefs and attachments into their lives (Sherkat 1997:66).

The degree of influence that religious values and beliefs have on inmates depends on social and communal attachments. Religious beliefs have the power to deter delinquent and criminal acts only when supported by social bonds. In summary, religious beliefs influence behaviour when they are part of social networks in which people are participants. Prosocial community contexts and networks of true friends and family help inmates to stay out of prison, once they have been released (Holsinger 2004:55). It is a challenge for most faith communities to be actively involved in the social support of families and inmates returning to various societies. Chaplains have the difficult task to assist in the creation and strengthening of external support systems beyond the prison walls for those who are about to be released into the community. Chaplains act as liaison between faith traditions and culture of prison and guide faith leaders to approaches and skills useful in penal systems. They encourage teachings and practices that are helpful and meaningful to inmates experiencing the challenges of prison life and culture.

\section{Programmes and interventions}

Pastoral interventions that focus on fear, make an emotional appeal or shame inmates do not work (see Scott 2008; Warren 2007; Zajac 2007). Non-directive, unstructured selfhelp programmes can be effective in other areas, but not for modifying the thinking patterns of inmates and for developing skills. Pastoral caregivers should focus on programmes that address particular issues and teach specific skills and techniques that are necessary for managing difficult situations.

Cognitive behavioural approaches are effective in a prison environment as they focus on the present, are task oriented, teach prosocial behaviours and techniques and provide inmates with an opportunity to practice this in safe environment (Brault 2014:3). Some religious services include programmes on anger management, grief, decision making, self-control, problem solving and forgiveness from a faith perspective. The programmes include examples of how to manage such situations through role play and offer opportunities to practice what is taught. A cognitive behavioural approach that is faith based can be seen as faithin-action (see Brault 2014:4). The approach shows how beliefs inform behaviour, how behaviour is impacted by beliefs and how to live out one's faith in a concrete way. Theological reflection on issues of faith in prison could serve as an instrument to support and nurture positive change in the lives of inmates. Various models of pastoral care serve different situations and purposes. The task is therefore to integrate spirituality and cognitive behavioural therapy in the counselling of inmates (Snodgrass 2009:219). On the whole, chaplains and pastoral caregivers assess, develop positive working relationships, evaluate change, engage skills and help people to find closure on issues affecting their lives and future.

Chaplains aim to develop an empathic understanding of and the ability to identify the strengths of inmates and help them to engage constructively with others. Many inmates distrust authority and have a history of abusive relationships. Building helpful rapport takes time and patience. Studies by Warren (2007) and Scott (2008) show that the probability of inmates embarking on a journey of change of lifestyle is determined by their abilities and their willingness to do so. Some inmates spend time to find the right programmes, books to read, study and otherwise gather information that will help them while in custody and thereafter. To increase 
the success rate of pastoral interventions, they are tailored to the stages and challenges of life in the prison environment. The chaplain's role is to support their commitment and help inmates to assess skills and activities that can foster change. They also help inmates to find solutions to problems and avoid the pitfalls of prison life (Brault 2014:5). The chaplain's role is not to 'fix' or change inmates. They provide a safe space where healing and change are possible. They aim to shift the attitudes, thoughts and self-control mechanisms of inmates so that they can make some positive changes. Coping skills are essential and necessary to rehabilitation efforts (Johnson 1996:98).

Mature coping skills are the core of correction and rehabilitation, which create the possibility of a more constructive and healthy life after prison (Johnson 1996:98). Studies conducted by Johnson (1996) show that mature coping skills increase prosocial attitudes and decrease anxiety and depression, disciplinary problems and punishment and generally improve health. Coping skills learnt in prison can be conducive to a more constructive life after release. Immature behaviour leads to failure and low self-esteem. It also inhibits a person's problem-solving capacity. Successful coping skills, on the other hand, build self-confidence and encourage people to participate in creative tasks and learn new skills. When religion forms part of how people cope, the outcome can be positive (see Bjorck \& Thurman 2007:159; Vandecreek et al. 2004:50; Wasserman, Weisman \& Suro 2013:16). Positive and mature religious coping skills help people to adjust better to the challenges they encounter in prison. Negative coping mechanisms correlate with increased depression, anxiety and stress.

Methods of coping that can make a positive contribution to people's lives include seeking positive religious support, forgiveness, purification and nurturing a sense of partnership with God, which enables people to relinquish control to God rather than centring control in themselves (see Brault 2014:6). A discontent with the social group and with God is often framed as punishment from God for sins committed through lack of faith. It is important that chaplains work towards building up the general and the religious coping skills of inmates.

In a study of the religious and spiritual experiences and beliefs of battered women who were in prison for the murder of their abusive partner, Schneider and Feltey (2009:443) found that spiritual experiences 'freed them' through providing them with means to reconstruct and reinterpret their victimisation and the perpetuation of crime. The women experienced love and acceptance as they were given the language to integrate their life story and claim new life through a theme of enduring hope and healing. Effective interventions should be culturally relevant, gender sensitive and trauma informed. Religious beliefs can also do harm. Female victims of domestic violence who turn to clergy for guidance and support sometimes encounter religious beliefs on patriarchy and the submissive role of women in the family, which lie at the heart of the violence they experienced in the home in the first place. Furthermore, a biblical emphasis on forgiveness, which places the responsibility on the shoulders of the victim, can be detrimental to those living with abuse (Giesbrecht \& Sevcik 2000:229). Chaplains should be conscious of the ways in which beliefs could help or harm those they serve and work with. They should provide positive and constructive interventions through teaching and encouraging spiritual practices such as prayer and meditation. The goal is to change the negative thinking, attitudes and action of people to positive and healthy ones through actions that lead to healing and hope.

The aim of chaplains should be to build good relationships and be a loving presence in a dark place. However, some use religion and their position in the system for other purposes. For some, religion is about status, social benefits, security and a positive self-image (see Pargament, Koenig \& Perez 2000:519; Sherkat 1997:65). Such an extrinsic orientation to religion can be seen as 'religious self-centredness'. Intrinsic religiosity is characterised by commitment to a calling and to the integration of their faith and their personal and professional lives. Religious practice is an end in itself where personal beliefs become the organising principles of a person's life. Intrinsic religiosity is closely linked to lower levels of anxiety, fear, depression and insecurity. It is conducive to integrated social behaviour, a sense of freedom and a more effective social adjustment. Extrinsic religious feelings can be linked to tendencies towards guilt, wrongdoing, anxiety and prejudice (Pargament et al. 2000:520). People with an intrinsic religious orientation are more effective in the penal system, both chaplains and inmates.

\section{Prison chaplaincy: An assessment}

Prison chaplaincy in Africa is generally structured on a 'onesize-fits-all' paradigm. Religious services are the main focus. Such services are often the only access inmates have to the outside world - to communities, culture, experiences and ideas. Studies on religion in prison focus mostly on programmes from a Christian and Protestant paradigm. The multi-faith setting of most prisons does, however, require that other faith traditions be incorporated. Christianity predominates in prisons, means that the experiences and perspectives of other faith traditions are often overlooked. Religious resources should be made available to all inmates, irrespective of their faith tradition. Chaplains as religious representatives are responsible for the quality of religious engagement in prisons.

Effective chaplaincy, pastoral care and counselling should be measured by how well the needs of the environment are assessed and how effectively pastoral practices respond to the needs. It is the responsibility of chaplains to help steer the process of change in penal institutions. Studies on prison chaplaincy mostly focus on the dynamics within the institutions. Pastoral care with people who have left prison is a dormant field that is yet to be investigated. If the prison environment is a challenge to people, readjusting to the 
outside world and reintegrating into communities and families may be even more complicated, especially because they not only have to fend for themselves economically, but face severe prejudice in trying to do so.

Ideally, prison institutions and the chaplains who work there should provide a freedom of worship as they make available opportunities for inmates to practice religion as an individual choice and way of life (see Paget \& McCormick 2006:4, 5). All are included, regardless of age, gender and ethnicity of faith tradition. A ministry of presence is in itself an important intervention (Paget \& McCormick 2006:11). Chaplains should respect cultural and religious differences and provide an opportunity for people to choose their own path. As they chart common ground, chaplains strive to build relationships that promote trust and encourage positive self-esteem and self-discovery. The role of the chaplain encompasses many pastoral and ministerial tasks. Pastors care for inmates' lives and relationships in prison. This care includes Scriptural instruction, interpretation, meditation, spiritual direction, presence, listening and reflection (Paget \& McCormick 2006:18). Chaplains are servant leaders who, along with other clergy and volunteers, perform various tasks and contribute diverse competencies to the prison environment (Paget \& McCormick 2006:iv). The goal is to equip and empower inmates to grow in knowledge, wisdom and spiritual maturity.

Chaplains constitute a symbol of morality and humanity in the harsh prison environment. Prison chaplaincy takes a form of care and support which differs from that of other professionals such as medical personnel, psychologists, psychiatrists and social workers. Chaplains are an independent source of support because they are not part of 'management' or part of the prison regime of rehabilitation and psychological evaluation. Their particular contribution and distinctive value in penal institutions rests on their independence and neutral status. Prison chaplaincy as a service in the penitentiary system is identified as apart from, rather than aligned with, discourses of control, discipline and punishment, as well as from the culture and life in prison. Their role is to ameliorate the effects of penal structures on the dignity and humanity of the inmates.

The practice of religion and spirituality converges well with African culture and can have a positive and grounding effect on the lives of people in detention centres. This calls for the integration of religious ethical principles of love and compassion into the penal system to make it more humane and conducive to the growth and development of the inmates. The goal should be to discover what insights, reforms and best practices could contribute to an improved praxis in the prisons of Africa. Pastoral care and prison chaplaincy should protect the sanctity of human life and secure freedom, forgiveness and reconciliation. If incarceration not only as 'punishment' but also specifically as 'rehabilitation' were to achieve its goal, the result should be positive behaviour, repentance, reconciliation and forgiveness. The ultimate outcome of the efforts of both the justice system and pastoral care of people in the prison environment should be the successful reintegration of people into society.

\section{Acknowledgements Competing interests}

The authors declare that they have no financial or personal relationships which may have inappropriately influenced them in writing this article.

\section{Authors' contributions}

This article is a reworked version of aspects from the $\mathrm{PhD}$ thesis of A.K.A. titled 'An African pastoral perspective on prison chaplaincy', in the Department of Practical Theology, University of Pretoria with Y.D. as supervisor.

\section{References}

African Commission on Human and Peoples' Rights (ACHPR), 2010, Activity report of the special rapporteur on prisons and places of detention in Africa, African Union, Banjul, Gambia.

Atabong, J., 2007, Opening new doors: Pastoral work in the prison, Wacha Business, Douala.

Bjorck, J.P. \& Thurman, J.W., 2007, 'Negative life event, patterns of positive and negative religious coping, and psychological functioning', Journal for the Scientific Study of Religion 46, 159-167. https://doi.org/10.1111/j.1468-5906.2007.00348.x

Brault, E.R., 2014, 'Pastoral care and counselling in prison: What works', Journal of Pastoral Care and Counselling 68(3), 1-10. https://doi.org/10.1177/154230 501406800306

Compendium, 2006, Catechism of the Catholic Church, United States Conference of Bishops, Washington, DC.

Denend, J., 2007, 'A new look at chaplaincy in a prison setting', Journal of Pastoral Care \& Counselling 61(4), 395-398. https://doi.org/10.1177/154230500706100416

Dissel, A., 2007, Rehabilitation and reintegration in African prisons: Human rights in African prisons, HSRC Press, Cape Town.

Foucault, M., 1979, Discipline and punish, Vintage Press, New York.

Giesbrecht, N. \& Sevcik, I., 2000, 'The process of recovery and rebuilding among abused women in the conservative evangelical subculture', Journal of Family Violence 15, 229-248. https://doi.org/10.1023/A:1007549401830

Graham, E., Walton, H. \& Ward, F., 2005, Theological reflection: Methods, SCM Press, London.

Griffith, L., 1995, The fall of the prison: Biblical perspectives on prison abolition, Eerdmans, Grand Rapids, MI.

Hausmann, E., 2004, 'Chaplain contacts improve treatment outcomes in residential treatment programs for delinquent adolescents', The Journal of Pastoral Care and Counselling 58(3), 215-224. https://doi.org/10.1177/154230500405800306

Hausmann, E. \& Spooner, M., 2009, 'Does pastoral counselling work? A pilot study of delinquent boys', Journal of Pastoral Care and Counselling 63(3-4), 4-1-4-6.

Holsinger, A., 2004, 'In their own voice: Assessing factors related to successful re-entry via offender focus groups', Offender Programs Report 7(5), 55-61.

Johnson, R., 1996, Hard time: Understanding and reforming the prison. Wadsworth, Belmont, $C A$.

Kim, B., 2001, 'Social constructivism', in M. Orey (ed.), Emerging perspectives on learning, teaching and technology, viewed n.d., from http://www.coe.uga.edu/ epltt/socialconstructivism.htm

Koenig, H., 1995, 'Religion and older men in prison', International Journal of Geriatric Psychiatry 10, 219-230. https://doi.org/10.1002/gps.930100308

Kusada, J.R., 2014, 'The perceptions and experiences of male offenders regarding social and rehabilitation services at Chikurubi Farm Prison in Zimbabwe', Unpublished master's thesis, University of Cape Town, Cape Town.

Maruna, S., Wilson, L. \& Curran, K., 2006, 'Why God is often found behind bars: Prison conversions and the crisis of self-narrative', Research in Human Development 3 , 161-184. https://doi.org/10.1080/15427609.2006.9683367

Paget, N.K. \& McCormick, J.R., 2006, The work of the chaplain, Judson Press, Valley Forge, PA.

Pargament, K.I., Koenig, H.G \& Perez, L.M., 2000, 'The many methods of religious coping: Development and initial validation of the RCOPE', Journal religious coping: Development and initial validation of the RCOPE', Journal
of Clinical Psychology 56, 519-543. https://doi.org/10.1002/(SICI)10974679(200004)56:4\%3C519::AID-JCLP6\%3E3.0.CO;2-1

Pew Forum on Religion and Public Life, 2012, Religion in prisons: A 50-state survey of prison chaplains, viewed n.d., from http://www.pewforum.org/Social-Welfare/ prison-chaplains-religious-volunteers.aspx 
Roberts, R.S.B. (ed.), 2012, Professional spiritual and pastoral care: A practical clergy and chaplains handbook, Skylight Paths, Woodstock, VT.

Romeril, J. \& Tribe, R., 1995, 'Prison pastoral care: How chaplains see their role', The Journal of Pastoral Care 49(4), 383-390. https://doi.org/10.1177/002234 099504900405

Schneider, R.Z. \& Kathryn, M.F., 2009. "No matter what has been done wrong can always be redone right": Spirituality in the lives of imprisoned battered women', Violence against Women 15(4), 443-459. https://doi. org/10.1177/1077801208331244

Scott, W., 2008, Effective clinical practices in treating clients in the criminal justice system, Department of Justice, National Institute of Corrections, Washington, DC.

Sekhonyane, M., 2005, 'Prison reform in Africa: Recent trends', Civil Society Prison Reform Initiative 10, 1-6.

Sherkat, D., 1997, 'Embedding religious choices: Preferences and social constraints into rational choice theories of religious behaviour', in L.A. Young (ed.), Rational choice theory and religion: Summary and assessment, pp. 65-85, Routledge, New York.

Skotnicki, A., 2008, Criminal justice and the Catholic Church, Rowan \& Littlefield Publishers, Plymouth, UK.
Snodgrass, J., 2009, 'Toward holistic care: Integrating spirituality and cognitive behavioural therapy for older adults', Journal of Religion, Spirituality, \& Aging 21 219-236. https://doi.org/10.1080/15528030902803913

Swinton, J. \& Mowat, H., 2006, Practical theology and qualitative research, SCM Press, London.

Thomas, J. \& Zaitzow, B.H., 2006, 'Conning or conversion? The role of religion in prison coping', The Prison Journal 86(2), 242-259. https://doi.org/10.1177/00328 85506287952

Vandecreek, L., Paget, S., Horton, R., Robbins, L., Oettinger, M. \& Tai, K., 2004 'Religious and nonreligious coping methods among persons with rheumatoid arthritis', Arthritis \& Rheumatism 51(1), 49-55. https://doi.org/10.1002/ art.20074

Warren, R., 2007, Evidence-based practice to reduce recidivism: Implications for state judiciaries, Department of Justice, National Institute of Corrections, Washington, DC.

Wasserman, S., Weisman, A. \& Suro, G., 2013, 'Nonreligious coping and religious coping as predictors of expressed emotion in $n$ relatives of patients with schizophrenia', Mental Health, Religion \& Culture 16(1), 16-30. https://doi.org/10 .1080/13674676.2011.64234

Zajac, G., 2007, Principles of effective offender intervention, Pennsylvania Department of Corrections, viewed 5 May 2012, from http://www.state.in.us/idoc/files/ PrinciplesofEffectivelnterventionPenn.pdf. 